Research Article

\title{
Fisheries management of diplodus sargus in the East of North Sinai
}

\begin{abstract}
Although there are many fisheries studies in North Sinai coast specifically in Bardwell lagoon, a few of them concern with fisheries study. During this study, 991 sample of white seabream were caught along the Eastern Mediterranean between September 2010 and April 2012 for management of Diplodus sargus fisheries. Total length was ranged from 11 to 38 $\mathrm{cm}$, represented age classes were between 1 and 5 years. Body weight of studied fish was ranged between 12 to $840 \mathrm{gm}$. Age, growth, condition factor and maximum sustainable yield (MSY) and its corresponding effort $\left(\mathrm{F}_{\max }\right)$ were estimated. By this study it was found that many of $D$. sargus in North Sinai coast caught were small in size and with level lower than maximum sustainable yield.
\end{abstract}

Keywords: North Sinai coast, Diplodus Sargus, Fisheries management, Maximum sustainable yield
Volume 6 Issue 2 - 2017

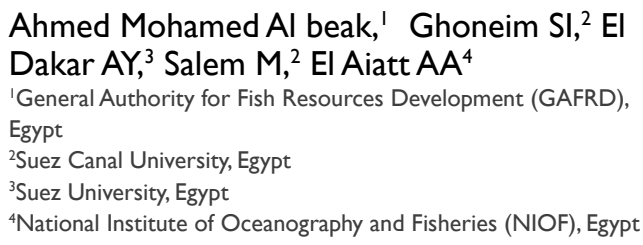

Correspondence: Ahmed Mohamed Al-beak, General Authority for Fish Resources Development (GAFRD), Egypt, Te +201007264406, Email albeak2020@yahoo.com

Received: December 12, 2016 | Published: August II, 2017

\section{Introduction}

Fisheries are the greatest users of marine resources in the Mediterranean. Commercial fishing tends to be concentrated in inshore areas, ${ }^{1}$ Mediterranean Sea-fishing production represents a limited proportion of the world production, which is about 100 million tons. The Mediterranean Sea fisheries can be broken down into three main categories: small-scale fisheries, trawling and seining fisheries. ${ }^{2}$

Seabreams (Sparidae) are a group of demersal perciform fishes of high commercial value, where it found in coastal waters world-wide and sustain important recreational and commercial fisheries. ${ }^{3}$ This family found in a wide variety of marine habitats, from rocky to sand bottoms, at depths between 0 to $500 \mathrm{~m}$, although they are usually more common at less than $150 \mathrm{~m}$ deep. ${ }^{3-7}$

Age information is important as it forms the basis for the calculations of growth and mortality rates and productivity estimates, ${ }^{8}$ making it essential for fisheries management. ${ }^{9,10}$

The aim of the present study is to learn about Diplodus sargus biology and its population dynamics, that it is necessary for fisheries management in the Eastern Mediterranean Sea at north Sinai coast and to provide valuable advice to the fisheries authority.

\section{Materials and methods}

During two seasons, 2011 and 2012, a total of 991 specimens of white seabream, D. sargus, (Total length, 11 to $38 \mathrm{~cm}$, total weight, 12 to 840 grams) were collected from mixed commercial catch by ElDabba (El-kanar) gear about 95\%, and by the Long line gear about 5\% from El-Arish Marin Seaport.

Five to six scales were removed below the pectoral fin, washed and stored dry in individually labeled container. In the laboratory, scales were washed with sodium hydrochloride (5\%) and cleaned with pure water and mounted dry between two glass slides, examined under a microscope $(5 \mathrm{X})$ to determine the age. The total scale radius and the distance from the focus to each annulus were measured using an eye piece micrometer.
Total length (TL) was measured to the nearest $\mathrm{mm}$ and body weight (TW) recorded to the nearest one gram. Back calculations lengths done from scale measurements by using Lea's equation (1910): $\mathrm{Ln}=$ $(\mathrm{Sn} / \mathrm{S}) \mathrm{L}$, where, $\mathrm{Ln}$ is the length of fish at age " $\mathrm{n}$ ", $\mathrm{Sn}$ is a magnified scale radius to " $n$ " annulus. S: is a magnified total scale radius. $\mathrm{L}$ is a fish length at capture.

Constants of Von Bertalanffy's growth equation calculated by applying Ford - Walford ${ }^{12,13}$ method .

Composite coefficient of condition factor "Kc" computed according to Fulton ${ }^{11}$ as:

$\mathrm{Kc}=(\mathrm{W} * 100) / \mathrm{L}^{3}$

Where, W: is the weight in gm, L: is the length in $\mathrm{cm}$.

The average length at first maturity $\left(\mathrm{L}_{\mathrm{m}}\right)$ calculated from an empirical relationship between length at first maturity and asymptotic length $\mathrm{L}_{\infty}$ (Froese and Binohlan). ${ }^{14}$

$$
\log \mathrm{L}_{\mathrm{m}}=-0.1189+0.9157 * \log \mathrm{L}_{\max }
$$

Where, $\mathrm{L}_{\text {max }}$ : are the maximum length reached by fishes.

Age at first maturity $\left(\mathrm{t}_{\mathrm{m}}\right)$ calculated from the length at first maturity using the inverse of the Von Bertalanffy's ${ }^{15}$ growth function. The length at first capture $\left(\mathrm{L}_{\mathrm{c}}\right)$, was determined from the accumulated catch curve as described in Pauly. ${ }^{16}$

Maximum sustainable yield (MSY) and its corresponding effort $\left(\mathrm{F}_{\max }\right)$ were estimated by Schaefer model (1954).

$\mathrm{C} / \mathrm{f}=\mathrm{a}+\mathrm{bf}$

Where: $\mathrm{C} / \mathrm{f}$ is the catch per unit effort.

$\mathrm{f}$ is the total effort.

"a and b" are constants to be determined empirically by the statistical linear regression between $\mathrm{C} / \mathrm{f}$ and $\mathrm{f}$.

The yield per recruit (Y/R) was estimated by Gull ${ }^{17}$ model. Beverton and $\mathrm{Holt}^{18}$ biomass per recruit $(\mathrm{B} / \mathrm{R})$ model was obtained by the equation: $\mathrm{B} / \mathrm{R}=\mathrm{Y} / \mathrm{R} / \mathrm{F}$ where " $\mathrm{F}$ " is the fishing mortality. 
Biological reference points "BRP", " $F_{\max }$ " and " $F_{0,1}$ " were obtained according to Cadima. ${ }^{19}$ The effects of age and length at first capture on yield per recruit at the present value of fishing mortality and at different fishing mortality values were estimated.

According to Cadima ${ }^{19} \mathrm{~F}_{\text {max }}$ is the point of the curve of yield per recruit $(\mathrm{Y} / \mathrm{R})$ against fishing mortality $(\mathrm{F})$, where $(\mathrm{Y} / \mathrm{R})$ is maximum. While, $F_{0.1}$ is the value of $(\mathrm{F})$ where, $(\mathrm{Y} / \mathrm{R})$ is equal to 10 percent of $(\mathrm{Y} / \mathrm{R})$ maximum.

\section{Results}

\section{Age and Growth}

Age Determination: Age determination is a central part of all work directed to the rational exploitation of a fish stock..$^{20-24}$ Knowing the age of a fish provides a clue to its longevity, age at first maturity, age of recruitment, and growth. ${ }^{25}$ Age determination of specimen as the annulus ring appeared as a thick dark zone. A total of five age groups were determined. The maximum group observed as 479 (48.3\%) fish corresponding $1^{\text {st }}$ year of life, followed by 330 fish corresponding $2^{\text {nd }}$ year of life. The $3^{\text {rd }}, 4^{\text {th }}$ and $5^{\text {th }}$ were represented by $18.4 \%$ only of total groups.
Growth in length and weight: The back-calculation length was determined of the white seabream $D$. sargus as $11.13,17.57,22.67$, 27.12 and $29.82 \mathrm{~cm}$ for ages $1,2,3,4$ and 5 years respectively. It is clear that, the highest increment in length for D. sargus occurred at the first year of life $(11.13 \mathrm{~cm})$ and then declined rapidly, reaching its minimal value during the five year of life (Table $1 \&$ Figure 1). It is clear that the highest increment in weight for D. sargus occurred at the end of fourth year of life as increment was (163.57 gm) and then declined rapidly thereafter, the back-calculated weight of $D$. sargus was 22.60, 95.69, 214.46, 378.03 and 510.92 gm, for ages 1, 2, 3,4 and 5 years as shown in Table $2 \&$ Figure 2.

\section{Theoretical growth in length and weight}

Theoretical growth in length and weight of $D$. sargus in the Eastern Mediterranean by solve Von Bertalanffy ${ }^{15}$ growth equation for length and weight and fitting the Ford \& Walford ${ }^{12,13}$ plot. Constants of Von Bertalanffy's growth equation $\left(\mathrm{L}_{\infty}, \mathrm{K}, \mathrm{t}_{\mathrm{o}}\right.$ and $\mathrm{W}_{\infty}$ ) by using Ford \& Walford ${ }^{12,13}$ method in the coast of North Sinai was $(40.71 \mathrm{~cm}, 0.2497$ year $^{-1},-0.2794$ year $^{-1}$ and $1368.1 \mathrm{gm}$, respectively).

Table I Back - calculated length of Diplodus sargus from the coast of North Sinai

\begin{tabular}{|c|c|c|c|c|c|c|c|}
\hline \multirow{2}{*}{$\begin{array}{l}\text { Age } \\
\text { (Year) }\end{array}$} & \multirow[t]{2}{*}{ No. of fishes } & \multirow[t]{2}{*}{ Observed length } & \multicolumn{5}{|c|}{ Back calculated total length $(\mathrm{cm})$} \\
\hline & & & I & 2 & 3 & 4 & 5 \\
\hline I & 479 & 15.88 & 11.13 & & & & \\
\hline 2 & 330 & 20.61 & 10.77 & 17.57 & & & \\
\hline 3 & 87 & 27.53 & 11.48 & 17.67 & 22.67 & & \\
\hline 4 & 54 & 30.69 & 11.19 & 17.9 & 22.7 & 27.12 & \\
\hline \multirow[t]{5}{*}{5} & 41 & 34.55 & 11.81 & 17.89 & 23.08 & 27.5 & 29.82 \\
\hline & Average & & 11.28 & 17.76 & 22.81 & 27.31 & 29.82 \\
\hline & Standard Deviation & & 0.39 & 0.16 & 0.23 & 0.27 & 0 \\
\hline & Increment & & 11.13 & 6.43 & 5.1 & 4.45 & 2.71 \\
\hline & $\%$ increment & & 37.33 & 21.57 & 17.11 & $14.9 \mid$ & 9.08 \\
\hline
\end{tabular}

Table 2 Back - calculated weight of Diplodus sargus from the coast of North Sinai

\begin{tabular}{|c|c|c|c|c|c|c|c|}
\hline \multirow{2}{*}{$\begin{array}{l}\text { Age } \\
\text { (Year) }\end{array}$} & \multirow[t]{2}{*}{ No. of fishes } & \multirow[t]{2}{*}{ Observed weight } & \multicolumn{5}{|c|}{ Back calculated total weight ( gm ) } \\
\hline & & & $\mathbf{I}$ & 2 & 3 & 4 & 5 \\
\hline I & 479 & 71.34 & 22.6 & & & & \\
\hline 2 & 330 & 170.85 & 20.34 & 95.69 & & & \\
\hline 3 & 87 & 434.1 & 24.91 & 97.53 & 214.46 & & \\
\hline 4 & 54 & 569.28 & 22.95 & 101.58 & 215.29 & 378.03 & \\
\hline \multirow[t]{5}{*}{5} & $4 I$ & 710.8 & 27.26 & 101.31 & 226.92 & 395.12 & 510.92 \\
\hline & Average & & 23.61 & 99.03 & 218.89 & 386.58 & 510.92 \\
\hline & Standard Deviation & & 2.61 & 2.89 & 6.97 & 12.08 & 0 \\
\hline & Increment & & 22.6 & 73.09 & 118.77 & 163.57 & 132.89 \\
\hline & $\%$ increment & & 4.42 & $|4.3|$ & 23.25 & 32.02 & 26.01 \\
\hline
\end{tabular}

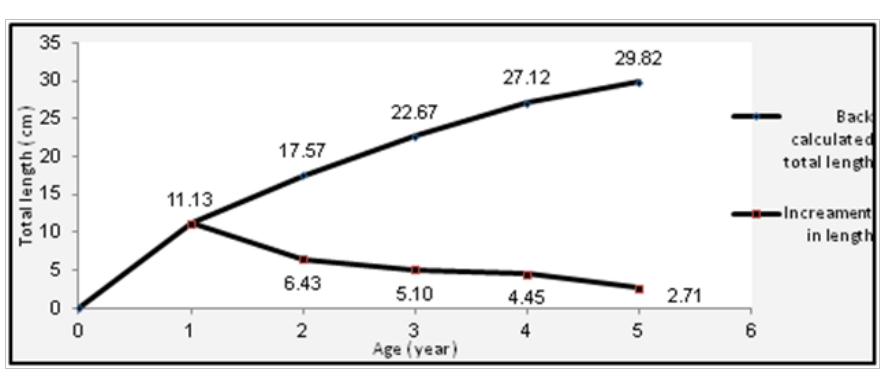

Figure I Increment in length of Diplodus sargus from the coast of North Sinai.

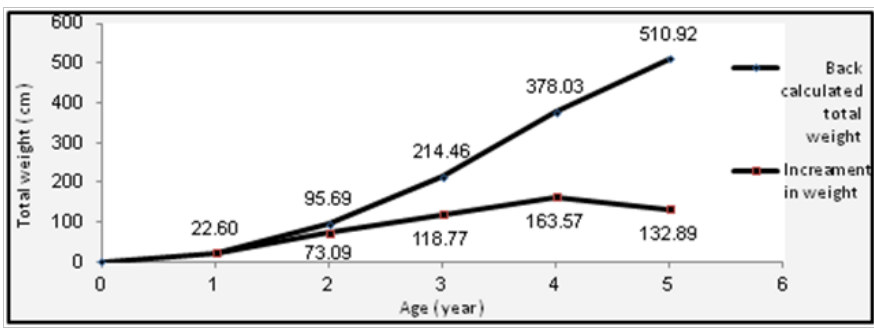

Figure 2 Increment in weight of D. sargusfrom the coast of North Sinai. 


\section{Condition Factor $(\mathbf{K c})$}

Composite coefficient of condition "Kc" of $D$. sargusis generally increases from the size range $(11-11.9 \mathrm{~cm})$, with least value about 0.90 to highest value 2.17 in size range (26-26.9) and its values stay irregularly in wide size range groups then it became about 1.53 in size range 38 - 38.9 (Figure 3).

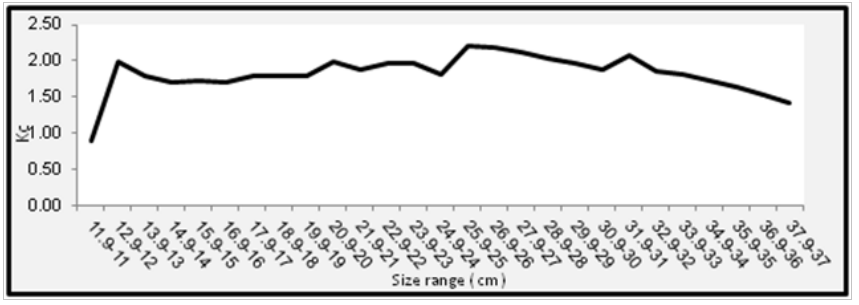

Figure 3 Composite coefficient of condition "Kc" of D. sargus from the coast of North Sinai.

\section{Estimation of length and age at first maturity $\left(L_{m}\right.$ and $\left.t_{m}\right)$}

Calculate age at first maturity from the length at first maturity by the inverse of the von Bertalanffy's ${ }^{15}$ growth function, for $D$. sargus in the Eastern Mediterranean the length $\left(\mathrm{L}_{\mathrm{m}}\right)$ was $21.27 \mathrm{~cm}$ corresponding age $\left(\mathrm{t}_{\mathrm{m}}\right) 2.68$ years.

\section{Estimation of length at first capture $\left(L_{c}\right)$}

The length at which the probability of capture is $50 \%$, length at first capture $\left(\mathrm{L}_{\mathrm{c}}\right)$ of $D$. sargus was $18.1 \mathrm{~cm}$ corresponding age $\left(\mathrm{t}_{\mathrm{c}}\right) 2.08$ years, where it described graphically (Figure 4).

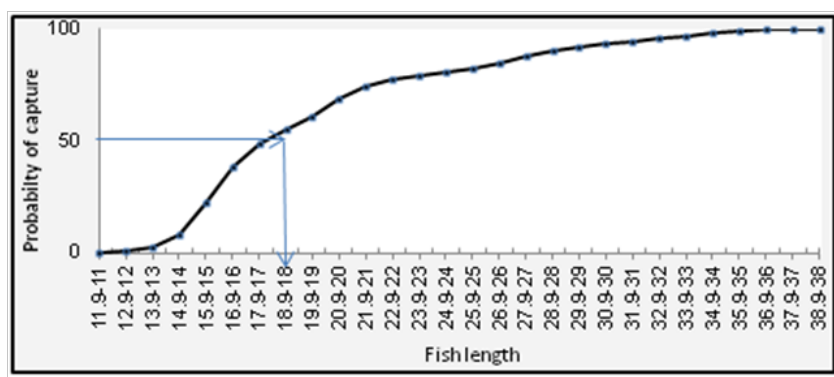

Figure 4 Cumulated catch curve of $D$. sargus from the coast of North Sinai.

\section{Management}

Maximum sustainable yield: The maximum sustainable yield (MSY) in the coast of North Sinai was 2579.24 tons and total fishing effort leading to the (MSY) by 803 units, the present total effort in the coast of North Sinai was 2334 tons in season 2012 by 531 units (Figure 5).

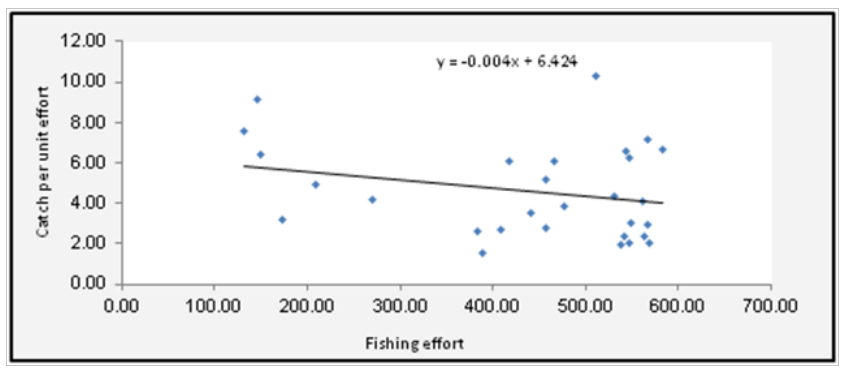

Figure $\mathbf{5}$ Catch per unit effort and fishing effort in the coast of North Sinai.

Yield per recruit $(\mathbf{Y} / \mathbf{R})$ and biomass per recruit $(\mathrm{B} / \mathrm{R})$ : The yield per recruit $(\mathrm{Y} / \mathrm{R})$ and biomass per recruit $(\mathrm{B} / \mathrm{R})$ of $D$. sargus in the
Eastern Mediterranean was found to be $88.84 \mathrm{gm}$ and $286.14 \mathrm{gm}$ respectively at the actual fishing mortality 0.310 year- 1 . For different values of fishing mortality coefficient effecting on yield and biomass per recruit results found that the maximum value of yield per recruit was $100.33 \mathrm{gm}$ with fishing mortality coefficient $\mathrm{F}=0.75$ year- 1 , This means that the present level of fishing mortality coefficient is lower than the fishing mortality coefficient produce the maximum yield per recruit. Biomass per recruit was decreased with the increasing of fishing mortality where it maximum (734.79 gm) at $\mathrm{F}=0$ (Figure 6).

Biological reference Points $\left(\mathbf{F}_{\max }\right.$ and $\left.\mathbf{F}_{0.1}\right)$ : In the present study we found that $\mathrm{F}_{\text {max }}$ was 0.75 year-1 with maximum yield per recruit $100.330 \mathrm{gm}$. The target reference point $\mathrm{F}_{01}$ of $D$. sargus was found to be $\mathrm{F}_{0.1}=0.35$ year $^{-1}$ with yield per recruit $\mathrm{Y}_{0.1}=91.750 \mathrm{gm}$ and biomass per recruit $\mathrm{B}_{0.1}=262.143 \mathrm{gm}$ (with percentage $35.38 \%$ from the virgin stock biomass). Which it is larger than the actual value of the fishing mortality $\mathrm{F}_{\mathrm{pr}}=0.3105$ year $^{-1}$ (Figure 7).

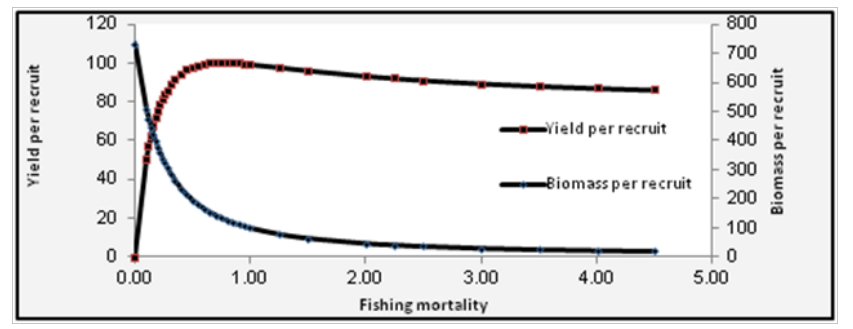

Figure 6 Yield per recruit and biomass per recruit of D. sargusfrom the coast of North Sinai.

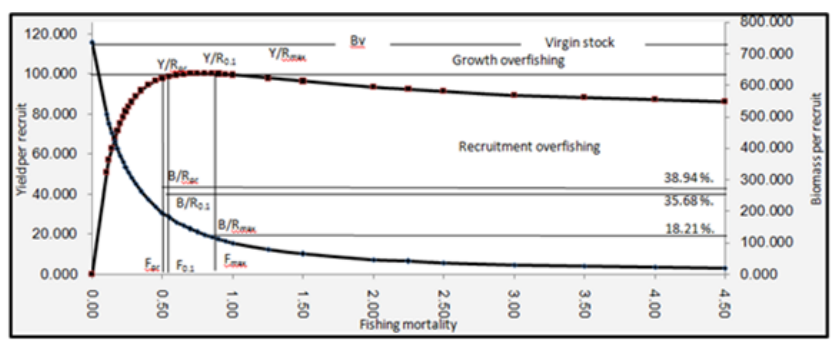

Figure 7 Yield per recruit according to the different values of fishing mortality $\left(F_{0 .}, F p r\right.$ and $\left.F_{\max }\right)$ of $D$. sargus from the coast of North Sinai.

\section{Discussion}

In spite of the wide distribution and importance of D. sargus there are just few publications existing on their fisheries managements. Fisheries management needs estimates of harvest level that provide maximum yield on a long term basis.

The concepts of fishery management are to provide advice on the optimum exploitation of aquatic living resources such as fish. Fisheries management needs estimates of harvest level that provide maximum yield on a long term basis. The most dominant age in the catch of D. sargus was age group 1, which it is similar with Man-Wai, Quignard \& Benchalel, Kara ${ }^{26,27}$ results.

Knowledge of growth and growth variability is essential to the understanding of a stock's population dynamics. To achieve an accurate assessment of these characteristics, several issues need to be addressed. The condition factor " $K$ " which was considered another way for expressing the relationship between length and weight.

The composite coefficient of condition "Kc" in this study is higher than Mouine et al..$^{28}$ coefficient of condition for D. Sargus that because the small lengths (group 1) have a highest value of condition factor than the older age group and it was dominant in this study. 
Age at first maturity of D. sargus was 2.68 years with length about $21.27 \mathrm{~cm}$ at current study, that less than Mouineet al. \& Benchalel and $\mathrm{Kara}^{27,28}$ which found age at first maturity were $20.5 \mathrm{~cm}$ for males and $21.4 \mathrm{~cm}$ for females corresponding four years. Fisheries biologists study fish habitat and fish populations, learning about the natural conditions that fish live in and then extending their knowledge to determine how a fishery can be used sustainable. ${ }^{29,30}$

Gulland ${ }^{17}$ model can be used to forecast the effects of development and management measures, such as increase or reduction of fishing fleets, changes in minimum mesh sizes, etc. Therefore this model forms a direct link between fish stock assessment and fisheries resources management. ${ }^{31}$ In the present study we found yield per recruit of $D$. sargus was less than the maximum yield per recruit we can be obtain, this means that the present level of fishing mortality coefficient is lower than the fishing mortality coefficient produce the maximum yield per recruit, but that isn't attain any obvious economic proceeds.

Calculating biological reference points $\left(\mathrm{F}_{\max }\right.$ and $\left.\mathrm{F}_{0.1}\right)$ give use good background about the fisheries status of D. sargus in East Mediterranean, where it lower than the target reference point $\left(\mathrm{F}_{0.1}\right)$ and certainly it did not reach the overexploited phase. The maximum sustainable yield (MSY) was 2579 tons that are more than the yield form the Eastern Mediterranean fishery El-Arish Seaport where it current value was 2334 tons in year 2012. ${ }^{32,33}$ From this comparison between (MSY) value and current value of yield in the Eastern Mediterranean fishery we can determine that it must to increase current yield to maximum sustainable yield.

\section{Conclusion}

From previous results we can deduct that in East Mediterranean fisheries the white seabream are not fully exploited, therefore we must find other new techniques to catch these fishes. Also, it must to be the length at fist capture equal to the length at first maturity to give these fishes chance to reproduction once time at least.

\section{Acknowledgments}

None.

\section{Conflicts of interest}

None.

\section{References}

1. UNEP/MAP. The State of Mediterranean marine and costal environment in the Mediterranean region. United Nations Environment Programme/ Mediterranean Action Plan (UNEP/MAP) - Barcelona Convention. 96. 2012;pp.

2. Papaconstantinou C, Farrugio H. Fisheries in the Mediterranean Mediterranean Marine Science. 2000;1(1):5-18.

3. Fischer W, Schneider M, Bauchot ML. Fiches FAO d'identification des espèces pour les besoins de la pêche. (Rev. 1). Méditerranée et mer Noire. Zone de pêche. Végétaux et Invertébrés. 1987;1.1:1-760.

4. Gonçalves JMS. Biologica Pesqueirae Dinamica Populacionalde Diplodus vulgaris(Geoffr) e Spondylio soma cantharus (L) (Pisces, Sparidae) na costa Sudoeste de Portugal. Universdado do Algarve, UCTRA, Faro. 2000;pp.369.

5. Gomes MC, Serrao E, Borges MdF. Spatial patterns of groundfish assemblages on the continental shelf of Portugal. ICES J. Mar. Sci. 2001;58(3):633-647.
6. Sousa P, Azevedo M, Gomes MC. Demersal assemblages off Portugal: mapping, seasonal, and temporal patterns. Fish. Res. 2005;75:120-137.

7. Monteiro P, Bentes L, Coelho R, et al. Age and growth, mortality, reproduction and relative yield per recruit of the bogue, Boops boops Linn'e, 1758 (Sparidae), from the Algarve (south of Portugal) longline fishery. J. Appl. Ichthyol. 2006;22(5):345-352.

8. Campana SE. Accuracy, precision and quality control in age determination, including a review of the use and abuse of age validation methods. Journal of Fish Biology. 2001;59(2):197-242.

9. Casselman JM. Growth and relative size of calcified structures of fish. Transactions of the American Fisheries Society. 1987;119:673-88.

10. Cailliet GM, Andrews AH, Burton EJ, et al. Age determination and validation studies of marine fishes: do deep-dwellers live longer? Exp. 2001;36(4-6):739-764.

11. Fulton TW. The rate of growth of fishes. $20^{\text {th }}$ Annual Report of the Fishery Board of Scotland. 1902 ;(3):326-446.

12. Ford E. An account of the herring investigation conducted at Ply Mouth. J Marin Biol. Ass. U.K. 1933;19:305-384.

13. Walford LA. A new graphic method of describing the growth of animals. Biol. Bull. Mar. Biol. 1946;90(2):141-147.

14. Froese R, Binohlan C. Empirical relationships to estimate asymptotic length, length at first maturity and length at maximum yield per recruit in fishes, with a simple method to evaluate length frequency data. J. Fish Biol. 2000;56(4):758-773.

15. Von Bertalanffy L. A quantitative theory of organic growth. (Inquiries on growth laws II). Hum Biol. 1938;10(2):181-213.

16. Pauly D. Fish population dynamics in tropical water: a manual for use with programmable calculators. ICLARM. Stud. International Center for Living Aquatic Resources Management, Manila, Philippines. 1984;pp.325.

17. Gulland JA. Manual of methods for fish stock assessment. Part (1). Fish population analysis. FAO Man. Fish Sci. 1969;4:154.

18. Beverton RJH, Holt SJH. On the dynamics of exploited fish population. Fishery Investigations, Series II (London). 1957;19:1-533.

19. Cadima LE. Fish stock assessment manual. FAO Fisheries Technical Paper. no. 303, Rome, FAO. 2003;pp.161.

20. Bagenal TB. The ageing of fish. Proceeding of an Intenational symposium on the Ageing of Fish. England, Unwin Brothers Limited, chessington KT9 2NY, UK. 1974;pp.114-123.

21. Daget J, Le Guen JC. Les criteres d'age chez les poisons. In: problemes d' ecologie: la demographie des population de vertbres. Masson et cie, paris. 1975;pp253-289.

22. Meunier FJ, Pascal M, Loubens G. Comparaison de methods squelettochronologiques et considerations fonctionnelles sur le tissu osseux acellulaire d' un osteichtyen du lagon neo-caledonien, Lethrius nebulosus (Forskal, 1755). Aquaculture. 1979;(17):137-157.

23. Mills KH, Beamish RJ. Comparison of fin ray and scale age determination for lake whitefish (Coregonus clupeaformis) and their implications for estimates of growth and annual survival. Can. J. Fish. Aquat. Sci. 1980;(37):534-544.

24. Panfili J, Pontual H de, Troadec JP, et al. Manual of fish Sclerochronology. Brest, France: IFREMER-IRD co-(edn). 2002;pp.464.

25. Summerfelt RC, Hall GE. Age and growth of fish. The Iowa stste University Press, Ames, Iowa, USA. 1987;pp.544.

26. Man-Wai R, Quignard JP. The seabream Diplodus sargus (Linne 1758) in Gulf of Lion: growth of the seabream and characteristics of landings from the commercial fishing grounds of Sete and Grau-du-Roi. Rev Trav Inst Peches Marit Nates. 1982;46(3):173-194. 
27. Benchalel W, Kara MH. Age, growth and reproduction of the white seabream Diplodus sargus sargus (Linneaus, 1758) off the eastern coast of Algeria. J. Appl. Ichthyol. 2012;29(1):64-70.

28. Mouine N, Francour P, Ktari M, et al. The reproductive biology of Diplodus sargus sargus in the Gulf of Tunis (central Mediterranean). Scientia Marina. 2007;71(3):461-469.

29. Jacot AP. Age, growth and scale characters of the mullets, Mugil cephalus and Mugil curema. Trans Amer Fish Soc. 1920;39(3):199-229.

30. Anderson RO, Neumann RM. Length, weight, and associated structural indices. In: Murphy BR \& Willis DW (Eds.), Fisheries techniques. ( $2^{\text {nd }}$ edn), American Fisheries Society, Bethesda, Maryland. 1996;pp.447-482.
31. Mahmoud HH, Osman AM, Ezzat AA, et al. Fisheries biology and management of Diplodus sargus sargus (Linnaeus, 1758) in Abu Qir Bay, Egypt. Egy J Aquat Res. 2010;36(1):123-131.

32. NSZ. Fish statistics year sheet, North Sinai Zone branch of General Authority for Fish Resources Development. Egypt. 2012.

33. Garcia SM. Long-term trends in small pelagic and bottom fisheries in the Mediterranean: 1950-2008. Plan Bleu UNEP/MAP Regional Activity Centre. Valbonne, France. 2011;pp.102. 